\title{
A HATÉKONY KÖRNYEZETTUDATOS NEVELÉS KRITÉRIUMAI
}

\section{CRITERIA FOR AN EFFECTIVE ENVIRONMENTAL EDUCATION}

\author{
Novák János \\ Óbudai Egyetem, Kollégium, Keleti Károly Gazdasági Kar Vállalkozásmenedzsment Intézet, \\ Biztonságtudományi Doktori Iskola,novak.janos@koll.uni-obuda.hu
}

\begin{abstract}
Environmental awareness could also be called environment management, since it is necessary to organize, or rather manage any activities performed in order to protect the environment. A person who cares about their environment in their own household performs organizational tasks that are far more complex than people living in households who don't care, or care less about their environment. Consider how much extra energy it takes to selectively collect plastic PET bottles, or to properly dispose of used batteries, compared to those who just dispose of these together with municipal waste, out of negligence or laziness. Many think that the activities of the average person don't matter since there are so many of us on Earth that a single person's efforts won't change anything. Man, as a living being, is not capable of making decisions that would solve problems emerging in the next 20, 30 or 40 years; we usually start dealing with issues that we think will matter within the next 2-3 years: but we have admit that 2-3 years are not enough to solve global environmental protection and climate change problems. This way of thinking can easily lead to the decline of humanity in the future.
\end{abstract}

Keywords: environmental awareness, education, future, sustainability.

\section{Összefoglalás}

A környezettudatosságot akár környezetmenedzsmentnek is hívhatjuk, hiszen a környezet megóvására organizált tevékenységeket úgymond menedzselni, szervezni szükséges. Egy olyan ember, aki törődik a környezetével a saját háztartásában, egy olyan szervezési feladatot lát el, amely sokkal komplexebb, mint az olyan háztartásban élők életvitele, akik környezetükre nem vagy csak kevésbé figyelnek. Gondoljunk csak bele, hogy mennyi plusz energiabefektetést jelent akár a műanyag PET-palackok különgyüjtése vagy az elhasznált elemek, rossz akkumulátorok megfelelő gyüjtése és leadása azzal szemben, akik ezeket hanyagságból vagy lustaságból a kommunális szeméttel együtt gyűjtik. Nagyon sokan úgy gondolják, hogy egy átlagos ember tevékenysége nem számít, hisz olyan sokan vagyunk a Földön, hogy nem változtat semmin, ha csak egy ember elkezdi óvni a környezetét. Az ember mint élőlény nem képes olyan döntéseket hozni, amelyek 20-40 év múlva bekövetkező problémákat oldanának meg, általában 2-3 éven belül bekövetkező problémákkal kezdünk el foglalkozni, de lássuk be, egy globális környezetvédelmi és klímaváltozási probléma megoldására 2-3 év nem elegendő. Ez a gondolkodásmód könnyen vezethet a jövőben az emberiség hanyatlásához.

Kulcsszavak: környezettudatosság, nevelés, oktatás, jövő, fenntarthatóság. 


\section{Bevezetés}

A környezettudatosság a XX. század végétől van leginkább jelen, amióta komolyabb figyelmet kapott az emberek és az azok által kifejlesztett technológiák miatt bekövetkezett, egyre növekvő ökológiai katasztrófa veszélye. 2020-ra az emberiség ökológiai lábnyoma már komolyan mérhető formát öltött, amely főleg a melegebb hónapok átlaghőmérsékletén látszik. Már az elmúlt pár hónap is megmutatta, hogy a bolygónk átlaghőmérséklete a korábbi évekhez képest rohamos ütemben növekszik.

Lehet szó a brutális méreteket öltő brazil erdőkitermelésekről és erdőtüzekről vagy a folyamatos légszennyezésről, amelynek legnagyobb okozói pont a legfejlettebb és legnépesebb országok. Muszáj realizálnunk, hogy a bolygónk és az emberiség megélhetése érdekében a jelenlegi megszokásaink és munkafolyamataink a fenntartható jövő szempontjából sem reálisak. Gyermekkorunkra visszaemlékezve, mindig voltak figyelmeztetések, hogy iparosodott és fejlődő társadalmunk milyen kihatásokkal lehet bolygónk ökológiai egészségére, azonban akkor még számunkra - ahogy másoknak is - ezek csak riogatásnak tűntek. Ennek fő oka, hogy maga a környezettudatosság mint alapvető ,jellem” nem volt szerves része a 90-es és 2000-es évek közoktatásának hazánkban, sem pedig külföldön, bár Európa területén már a 70es évektől indultak törekvések a közös környezetvédelemi politika irányába. 1972-ben megállapí- tották a közös környezetvédelmi politika szükségességét. 1987-ben jött létre az egységes európai okmány új, „Környezet” elnevezésű címe, amely a közös környezetpolitika első jogalapjaként funkcionált. A jelenkor Európájában, a folyamatosan erősödő és teret nyerő „zöld pártok” támogatottsága is azt mutatja, hogy a környezettudatosság és az arra való igény jelentős mértékben növekedett az elmúlt évekhez, sőt évtizedekhez képest a választópolgárok körében. Ez a tendencia arra enged következtetni, hogy társadalmunk körében egyre nő azok száma, akik érdekeltek egy fenntartható és környezetbarát jövő kialakításában. Véleményem szerint, az emberiségnek jelenlegi technikai tudásával képesnek kell lennie arra, hogy egy olyan jövőt kivitelezzen a következő generációk számára, amely környezeti és energetikai szempontból élhetőbb lesz a jelenleginél. Ennek a célnak az eléréséhez azonban több alapvető dolgon fejleszteni és újítani kell, például az oktatásban; legyen szó akár a felnövő vagy a már felnőtt generációkról.

\section{Környezettudatos magatartásforma és a nevelés}

Magát a környezettudatos gondolkodásmódot több csatornán és több fázisban lehet a gyerekek számára egy alapvető elvvé, értékké formálni az oktatáson keresztül. Sajnos, jelenleg a klíma- és környezetvédelmet szinte alig vagy egyáltalán nem oktatják az általános, illetve középiskolák-

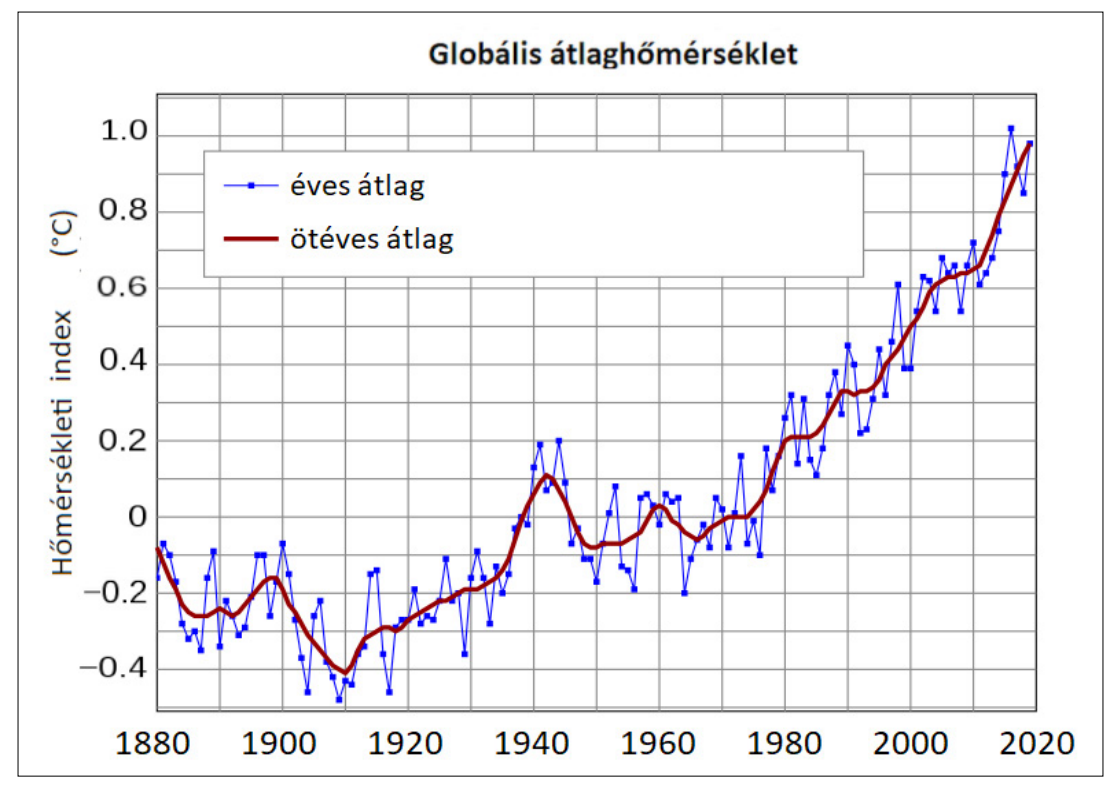

1. ábra. Hőmérsékleti index 1880-tól napjainkig [1] 
ban, gimnáziumokban. Ezen a vonalon, a világon elsőként, Olaszországban sikerült forradalmasítani az oktatás ilyen irányú hiányosságát, ahol hivatalosan is bekerült a tananyagba a „klímaváltozás” elnevezésű tantárgy, az állami iskolai tananyagban jövőre már szerepelni fog a klímaváltozás és a fenntartható fejlődés tudatos oktatása. Az olasz oktatásügyi miniszter, Lorenzo Fioramonti elmondta, hogy „az iskolások a következő tanévben 33 órában kötelezően foglalkoznak majd a klímaváltozás hatásaival”. A miniszter hangsúlyozta, kezdeményezése arra irányul, hogy a tanulók következő generációja megismerkedjen a klímaváltozás okaival, kockázataival és hatásaival [2]. Fontos már fiatalon egy olyan gondolkodásmódot kiépíteni a gyerekekben, amely nemcsak célravezető és produktív, hanem a környezettudatosság által képes új és alternatív módokon értékeket teremteni. Ezért, a másik fő csatornán, a közoktatáson kívül a család és az azonbelül folyó tudatos nevelés a környezettudatosságra a másik fontos tényező. Ennek eszközei lehetnek olyan „apróságok”, mint a szelektív hulladékgyűjtés vagy az arra alkalmas dolgok otthoni (házi) újrahasznosítása. Számíthat a későbbiekben egy olyan ökológia énkép kialakítása, amely kapcsán a gyermek érezheti, hogy majd a felnőttkori élete, illetve munkája milyen ökológiai lábnyomot hagyhat maga után. Ezáltal a későbbi iskolai oktatásban szereplő tananyag egy fontos kiegészítő szerepet és jelentést is elnyerhet. A jelenkorunk környezetvédelemmel foglalkozó oktatásának másik fő kihívása a már dolgozó emberek kész mechanizmusokkal operáló munkafolyamatainak, „zöldebb” átgondolásának motiválása, főleg a kis- és középvállalkozásokban. Saját munkahelyemen is megfigyelhetően tapasztalom a „régi, de működik” elv fennállását, amely által néha már-már irreális mennyiségű irodai (papír-, műanyag) hulladék keletkezik. Ezeket többnyire már vagy a technika, vagy egyéb, zöldebb megoldás felválthatná, ha az adott cégen belül egy külön szemponttá válna a profiton kívül is a jövő fenntarthatósága. Ennek a már kialakult problémának megoldása lehetne egy úgynevezett környezeti és fenntarthatósági továbbképzés elterjesztése, amely által a dolgozók is átformálhatnák a már kialakult gondolkodásmódjukat, és akár új (zöldebb, olcsóbb) megoldásokat is felfedezhetnének, később beépítve ezeket a mindennapjaikba. 14-16 éves korban már szellemileg és érzelmileg is nagyon fogékonyak a környezeti gondokra a fiatalok. Ekkor kezdik átlátni a világot, érzékelik és értik a fonák helyzeteket, érzelmileg és értelmileg is nagyon nyitottak [3].
Fontos, hogy a környezeti nevelés a környezetvédelem-gazdaság-társadalom viszonyrendszerében készítse fel a gyermeket az összefüggések és sokszor, sajnos, az egymást gátoló célrendszerek felismerésére, ebben a korlátozott döntési térben pedig a legoptimálisabb és etikus döntések meghozatalára (például növekedés és munkahelyteremtés kontra környezetszennyezés viszonya). A környezeti nevelés azáltal válik teljessé (holisztikussá), hogy kiterjed a mentálhigiéniás egészség területére, a pszichés egyensúly és harmónia létrejöttének nevelési lehetőségeire. A környezeti nevelés a jövőre irányul, a jövő kihívásaira való felkészítés a jelen nehéz körülményei között [4].

A környezeti nevelés céljai, feladatai (a teljesség igénye nélkül):

-ismeretterjesztés (természet, földrajz, élővilág, biológia);

-készségalakítás és képességfejlesztés (harmóniára való törekvés, problémamegoldó gondolkodás, döntés képesség fejlesztése);

- tudatformálás (ökológiai szemlélet és szépérzék, holisztikus szemléletmód);

- értékközvetítés (legfontosabb elve, hogy a következő generációk számára is csodálatos hely maradjon a Föld).

\section{Hiányosságok az elemi oktatásban}

Magyarországon a környezeti nevelés egy olyan téma, amely folyamatosan foglalkoztatja a magyar pedagógusokat és a szerveződés honlapján ofi.hu - a mai napig folyamatosan friss kutatások kerülnek fel a téma nemzetközi és magyar vonatkozásában. Ezek kiterjednek az új alkalmazható módszerekre és ezek hatékonyságára egyaránt. A magyar környezeti nevelés egyik legnagyobb hiányosságai közé tartozik, hogy a megelőzés nem kap kellően nagy hangsúlyt az oktatásban. A témának magyar pedagóguskörökben egy elég konzervatív értelmezése van elterjedve, ami a hagyományos módszerekre korlátozódik, mint például a szelektív hulladékgyűjtés vagy a kreatív újrahasznosítás. Ezenkívül a „környezet” kifejezést sokszor korlátozzuk a természetben található környezetre, míg a városi környezet szóba sem kerül. A magyar oktatási rendszer egyik legnagyobb hibája, hogy az oktatás egy 45 percre szabdalt mintát követ, és így elsikkadhatnak a fontos összefüggések. A rendszerszemlélet nélkül pedig nemcsak a környezeti nevelés elveinek átültetése, hanem más dolgok oktatása is nehezebbé válik. Hazánkban is nagy számban találhatóak már a kisóvodásokat is környezettudatos nevelésben részesítő öko- és zöldóvodák és általános iskolák, 
továbbá a környezettudatos nevelésnek komoly pedagógiai eszköztára és szakirodalma jött létre. Ezek közé tartozik a szociálpszichológusok, cselekvéspedagógusok, frontális oktatásban résztvevők kompetenciái, tudásbázisa. Az Ökoiskola-program jó dolog, viszont ez azt is jelenti, hogy a környezettudatosság még mindig egy olyan dolognak minősül, amelyet nem érez minden oktatási intézmény magáénak. A másik hangsúlyosabb probléma a megközelítésben rejlik. A gyermekek elsősorban a problémákkal találkoznak, amelyek már régen túl nőttek rajtuk - például a globális felmelegedés -, ráadásul azokat nem ők okozták, hanem az előző generációk. Fontosabb lenne arra rámutatni, hogy mit tehetnek ők a környezetükért. Ezekre a hiányosságokra kínál megoldást több program és szakképzés is, amelyek a pedagógusok környezeti neveléssel kapcsolatos ismereteit célozzák. Ezek nagy része költségekkel jár, mert független akkreditált egyesületek szervezik azokat. Állami intézményekben is fellelhető néhány hasonló továbbképzés. Szintén az elemi oktatás hiányosságainak rovására írhatók a későbbi fejlődés során kialakult ún. észlelési hibák, hiszen az oktatás kezdeti szakasza nagy részben befolyásolja a közép- és felsőoktatásban a tanulási mechanizmusokat.

\subsection{A környezettudatos magatartást érintő észlelési hibák}

Érdekes megfigyelni, hogy a környezettudatos tevékenységben, a döntéshozatalban mennyire jelen vannak és kézzelfoghatóak a tudás és a döntés szubjektivitását igazoló észlelési hibák:

-sztereotípiák és kategorizálások - az atomerőmű és az atomenergia zöldenergia, a hibrid autó az környezetkímélő;

- Halo effektus - a kis kocsi, az keveset fogyaszt;

- negatív torzítás - a diesel üzemű gépkocsi, az mind nagyon környezetszennyező;

- projekció - a zöldszervezetek (pl. a Greenpeace) azok erőszakosak;

- szelektív érzékelés - a bálnavadászat nem érdekel, nem érint, nem jut el a tudatomig;

- okság és korreláció - a globális felmelegedésnek semmi köze az emberi tevékenységekhez, sőt, nincs is globális felmelegedés;

- okság - a környezetvédelem drága és munkahelyet veszélyeztet.

\section{4. Összegzés}

Léteznek már olyan gazdaságfejlődési modellek, amelyek képesek megőrizni a természeti erőforrásokat a következő generációk számára is. Ehhez viszont szükséges a megújuló erőforrások használata, a pazarlás nélküli fogyasztói magatartás, illetve az anyag- és energiatakarékos termelés. Ezekben a modellekben a világ nemzetei többnyire olyan formában jelennek meg, melyben a növekvő létszámú emberiség oly módon használja a rendelkezésre álló forrásokat, hogy az elérhető maradjon az elkövetkező nemzedékek számára is [5].

Olyan mértékű az emberi rombolás, hogy néhány száz éven belül a Földünk lakhatatlanná válik. Hatalmas lesz a hőség és szárazság, a levegő pedig lélegezhetetlen lesz. Hawking szerint 2600ra a bolygónk a Vénuszhoz hasonló tűzgolyóvá válik majd. Ebből is látszik, hogy egyáltalán nem elég, ha csak a környezetvédőkre, illetve az államra bízzuk a környezetet, a polgároknak is meg kell érteniük az ügy súlyosságát, és el kell kezdeniük környezettudatosan élni, nemcsak a saját, hanem gyermekeik, unokáik jövőjének biztosítására is. Ahogy a Föld népessége növekszik, úgy egyre nagyobb nyomást gyakorlunk a környezetre. Ha ez a fajta nyomás meghaladja a környezet regeneráló, illetve megújító folyamatait, komoly következményeket von maga után. Ez okból, napjainkban sokkal nagyobb figyelmet kell fordítani környezetünk védelmére, mint eddig bármikor.

„Te légy a változás, ha látni akarod a világ változását." (Mahatma Gandhi)

\section{Szakirodalomi hivatkozások}

[1] https://stq.m.wikipedia.org/wiki/Bielde:Global_ Temperature_Anomaly.svg (letöltve: 2020.03.01)

[2] Magyar Nemzet: Elsőként a világon az olasz iskolai tananyagba kerül be a klímaváltozás 2019. november 06. (letöltve: 2020.03.02)

https://magyarnemzet.hu/kulfold/elsokent-a-vilagon-az-olasz-iskolai-tananyagbakerul-be-a-klimavaltozas-7466894/

[3] Magyar Közlöny, 2003/43/II. szám. 434.o.

[4] Havas P.: A biológia tanítása és a környezeti nevelés. (letöltve: 2020.03.03)

http://korlanc.uw.hu/download/cikk4.htm

[5] Barbier E. B., Markandya A.: A New Blueprint for a Green Economy. Routledge, 2013. 